C.M. Русіна,

Н.С. Карвацька,

\title{
B.I. Курик,
}

\section{Р.А. Нікоряк,}

\section{Т.Г. Карвацька}

Вищий державний навчальний заклад України "Буковинський державний медичний університет”, м. Чернівці

Ключові слова: психосексуальний розвиток, сексуальна поведінка та обізнаність, школярі.

\section{ОСОБЛИВОСТІ ПСИХОСЕКСУАЛЬНОГО РОЗВИТКУ СУЧАСНИХ ШКОЛЯРІВ}

\begin{abstract}
Резюме. Сексуальне здоров'я - важлива складова стану здоров'я людини і залежить не стільки від біологічних, скільки від психологічних і сочіальних факторів, індивідуальної та загальносуспільної культури і від мотивації сексуальної поведінки.
\end{abstract}

\section{Вступ}

Сексуальне здоров'я - невід'ємна складова фізичного і психічного здоров'я людини $[1,8,15$, 18]. Основними факторами, які впливають на сексуальну поведінку, є як біологічні (вроджені), так і набуті риси поведінки, які формуються в оточуючому середовищі однолітків чи старших із врахуванням їхньої думки, досвіду, базуються на авторитеті більшості, статевому вихованні (сім'я, школа, вулиця) та дії чи бездіяльності соціального контролю з боку суспільства [ 4-6,10-12].

Відповідно до технічних консультацій з питань сексуального здоров'я під егідою ВООЗ, проведених у 2002 році, встановлено, що кожна людина має право на інформацію, пов'язану із сексуальністю та статеву обізнаність, що відіграє визначну роль саме у підлітковому віці, коли відбувається посилення сексуального інтересу, а з настанням статевого дозрівання з'являється статевий потяг. ВОО3 у 2002 році провела обстеження близько 34 тисяч учнів 15-ти років із 24 держав світу, в якому підлітки висловлювалися з приводу сексуальної активності. Дослідженнями встановлено, що Україна знаходиться у середині списку і доля сексуально освідчених серед осіб у віці 15 років становить $25,1 \%$ юнаків та $24 \%$ дівчат у співвідношенні 1:1 порівняно з Македонією як 11:1 юнаків до дівчат $[2,3,9,16]$. Сексуальність являє собою рушійну силу соціальної активності людини, оскільки спрямована не тільки на досягнення сексуального задоволення, але і соціально-психологічного стану, який визначається як "щастя" та підвищує якість життя [7, 13]. На сьогоднішній день через існування та поширення СНІДу в Україні тема статевої обізнаності людей стала актуальною $[14,17]$.

\section{Мета дослідження}

Дослідити особливості психосексуального розвитку та сексуальної обізнаності школярів.

\section{Матеріал і методи}

Проведено дослідження 120 підлітків ЗОШ (по 60 підлітків із сільських та міських шкіл) віком $16,00 \pm 1,6$ років. Дівчата $15-17$ років становили по $50 \%$ мешканців села і міста. Юнаків було по 30 осіб із сільських та міських шкіл. Використовувалося анонімне опитування із застосуванням методу клінічного інтерв'ю. Статистичну обробку даних здійснювали 3 використанням критерію Стьюдента.

\section{Обговорення результатів дослідження}

Згідно з проведеними раніше дослідженнями сексуальності, які були у протиріччі (в багатьох державах світу, а саме східних) панівної моральності та духовності із фізіологічними потребами людини науковими дослідженнями встановлено, що на етапі формування психосексуальної орієнтації саме досліджуваний нами вік 15-17 років потрапляє у стадію формування еротичного (15 років) та сексуального (16-17 років) лібідо, залишаючи платонічне лібідо із обожнюванням, платонічними мріями, фантазіями та спілкуванням у минулому (до 15 років). Серед дівчат сільської ЗОШ теоретичну сексуальну обізнаність мали $73,33 \%$ та 100\% юнаків. Натомість теоретичний досвід серед міських школярів обох статей становив $100 \%$.

Формування сексуальності пов'язано із умовами життя, соціального оточення. Тому джерелом теоретичного досвіду у проведених дослідженнях відзначені серед сільських підлітків уроки біології, 
перегляд телевізійних передач, кіно, журнали, поради друзів, і тільки у $12 \%$ осіб знання черпалися 3 інтернету. Натомість міські підлітки основну свою сексуальну обізнаність отримували з інтернету (найпоширенішого неконтрольованого анонімного, дешевого ресурсу). На другому місці відзначали джерелом обізнаності спеціальну літературу, досвід друзів. На третьому місці обстежені виділили роботу деяких шкільних психологів iз статевого виховання. Жоден підліток із обстежених не висловився на користь сексуальної обізнаності, яку він отримав у сім'ї. Тому на сьогоднішній день через утримання серед дорослих моралістів репресивного відношення до сексуальності підлітки отримують неформальну сексуальну обізнаність переважно через веб-сайти, які відвідують як дівчата (до 73\%), так і юнаки $(100 \%)$.
Практичний досвід серед дівчат віком 15-16 років із сільської ЗОШ не відзначив ніхто, а серед 17-річних - 10\% осіб.

Натомість серед юнаків практичний сексуальний досвід констатували 20 \% 15-річних , 60 \% 16-річних та 70 \% 17-річних школярів. Дослідження міських школярів жіночої статі встановило, що практичний сексуальний досвід мали $20 \%$ 15-річних, 30 \% - 16-річних та 30\% - 17-річних школярок. Серед юнаків із міської ЗОШ сексуальний досвід був вищим, а саме: 15-річні становили $40 \%$ осіб, 16-річні - 80\% осіб, 17-річні - 60 $\%$ осіб, що видно з рис. 1.

Підлітковий вік пов'язаний зі статевим дозріванням. Тому для них важливою є якість життя із суб'єктивним благополуччям, психологічною інтимністю. Перебуваючи у віці 15 років, для яко-

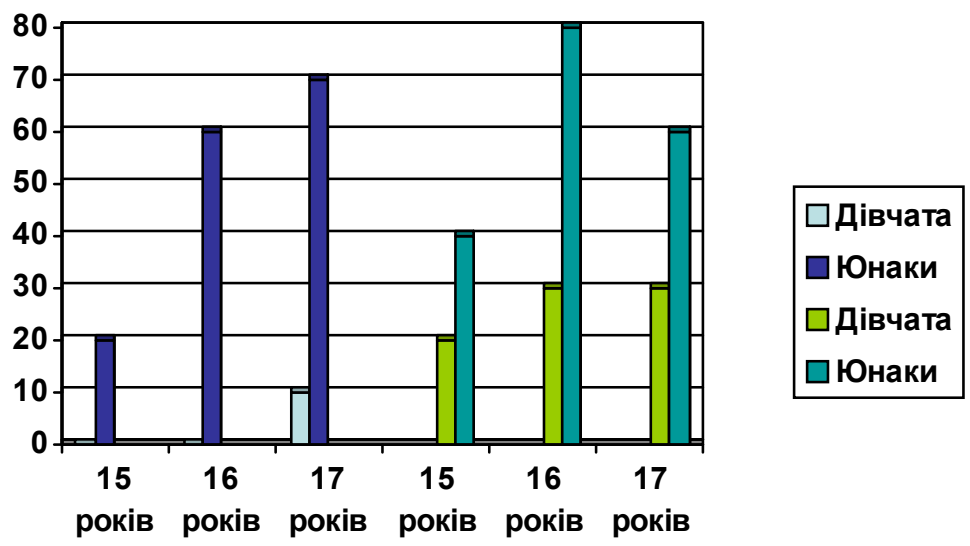

Рис.1. Практичний сексуальний досвід серед сільського і міського підліткового контингенту

го характерно формування еротичного лібідо 3 еротичними фантазіями, ласкою та грою, обстежені дали відверті анонімні відповіді й на питання початку сексуального життя. Вік, в якому $17-$ річна сільська школярка вступила в інтимне життя, становив 16 років. Натомість міські школярки в $23 \%$ випадків вказали на 15-річний вік, $33 \%$ осіб - 16-річний вік. Сільські юнаки у 8,4 \% випадках відзначали вступ у перший сексуальний зв'язок у 13-річному віці, 8,4 \% - у 14-річному віці, $50 \%$ - у 15-річному віці, по $16,6 \%$ осіб у 16-річному та 17-річному віці.

Серед досліджуваних юнаків міста практичний сексуальний досвід мали 18 осіб з 30 школярів, тобто 60\% досліджуваних даної групи. Вік, в якому 14-річні отримували перший сексуальний досвід, становив 16,6\% осіб, у 15-річних $50 \%$ осіб, а 16-річні - 33,4\% осіб, що видно з рис. 2.
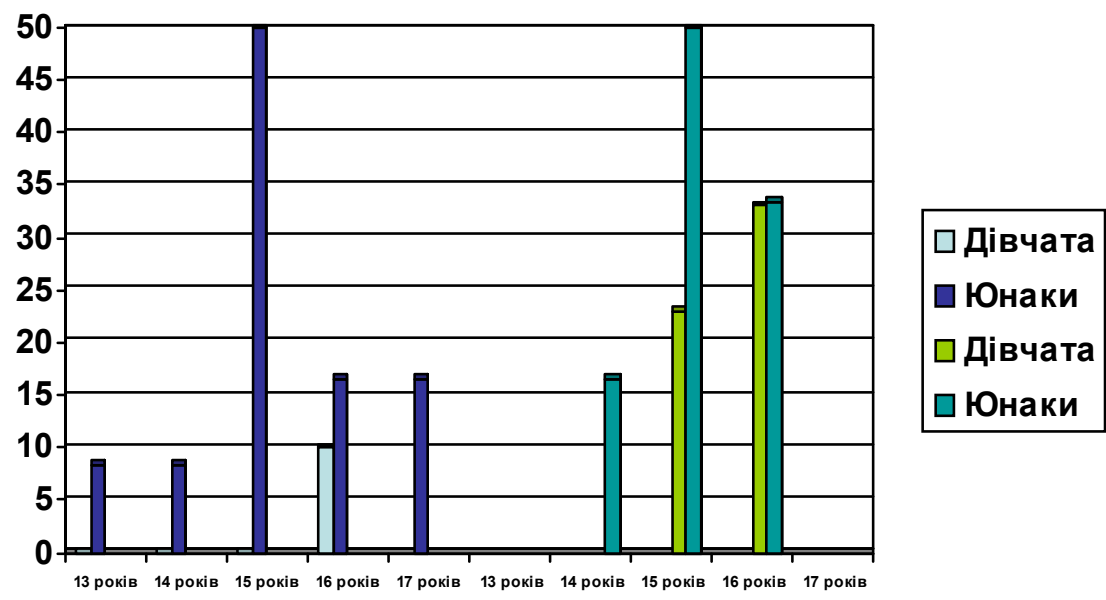

Рис. 2. Вік отримання першого сексуального досвіду 
У дослідженнях брали участь школярі 15-17 років, саме в тому віці, коли формується особистість, соціальна свідомість, адекватна оцінка своїх здібностей і потреб, формується власне світобачення. Відчуваючи себе дорослими, серед досліджуваних школярів сільської місцевості, близькі статеві стосунки відзначали 13 осіб, а серед школярів міста - 26 осіб у співвідношення 1:2, тобто 39 осіб із 120 досліджуваних мали статеві зв'язки, що становило $33 \%$. Через підліткову емансипацію від сім'ї (за відсутності порозуміння у сексуальній обізнаності) підліток у неформальній групі ровесників отримує сексуальну інформацію і перший сексуальний досвід. Мотивацією інтимних зв'язків у $11 \%$ осіб була закоханість із чуттєвою (еротичною) насолодою, у 16 $\%$ осіб - пізнання та задоволення цікавості, у 6\% осіб - фізіологічною необхідністю та потребою сексуального самоствердження. Лібералізація моралі на сучасному етапі та крах традиційних антисексуальних канонів суспільства призвели до того, що у сексуальності перестали бачити щось заборонене, незмінне. Реабілітована еротика, яка знаходить різні вираження у масовій культурі, а саме: у кіно, літературі, мистецтві.

На питання ставлення до інтимних зв'язків серед 30 досліджуваних школярок сільської ЗОШ позитивно висловилися 2 (7\%) осіб, негативно - 20 (67\%) осіб, нейтрально - 8 осіб, що становило 26 $\%$. Натомість серед 30 юнаків села сексуальну близькість сприймає позитивно 15 (50 \%) осіб, негативно - 5 (17\%) осіб, нейтрально - 10 (33\%) осіб. На сучасному етапі спостерігаються зміни в системі соціалізації підлітків через розширення діапазону контактів у сумісній діяльності юнаків і дівчат, що сприяє вирівнюванню традиційних гендерних особливостей, а послаблення зовнішнього суспільного контролю дає молоді незрівнянно більшу свободу у прийнятті рішення з питань статевого життя. Раннє статеве дозрівання та початок сексуального життя, як наслідок акселерації, випереджає сексуальний інтерес на 3-4 роки порівняно $з$ минулими поколіннями задовго до настання повноліття. Тому позитивне ставлення до раннього сексуального життя у 10 школярок міста становило $33 \%$ осіб, у 18 (60 \%) дівчат негативне, 2 (7 \%) осіб висловились нейтрально. Натомість позитивно серед юнаків висловились 20 (67\%) осіб, нейтрально - 7 (23\%) осіб і лише 3 (10\%) осіб - негативно.

Таким чином, збільшення стихійних середовищних впливів у поєднанні із скритністю підлітків створює сприятливе тло для порушень становлення сексуальності за відсутності послідовного суспільного статевого виховання.

\section{Висновок}

Отже, результати проведених досліджень засвідчили, що широкий доступ до різноманітної і не завжди адекватної інформації, відсутності у більшості родин важелів духовного і сексуальноетичного виховання підлітків призводить до зміни їхньої сексуальності та раннього сексуального життя.

\section{Перспективи подальших досліджень}

Вивчення підліткової мотивації сексуальної поведінки та раннього сексуального життя зобов'язує створити систему сексуальної освіти, що буде навчати молодих людей відповідальному відношенню до їх власної сексуальності.

Література. 1.Адлер А. Воспитание детей: Взаимодействие полов / [Пер. с англ. А.А.Велеева, Р.А. Валеева]. Ростов н / Д: Феникс, 1998. - 413 с. 2.Дебра Хепенни Чиавола. 50 отличных советов и приемов того, как найти общий язык со своим ребенком-подростком / Дебра Хепенни Чиавола// - Ростов н / Д: Феникс, 2005. - 120 с. 3.Дерягин Г.Б. Криминальная сексология / Г. Б. Дерягин. - М., 2008. - 552 с. 4.Доморацький В.И. Медична сексологія і психотерапія сексуальних розладів / В.И. Доморацький. - М., 2009. - С. 10 - 89. 5.Игумнов С.А. Психотерапия детей и подростков / С.А. Игумнов. - Ростов н / Д; Феникс, 2005. - 287 с. 6.Кон И.С. Психология старшеклассника / И.С. Кон. - М.: Просвещение, 1980. - 192 с. 7.Кон Н.С. Сексология /Н.С. Кон // - М., Academia. 2014. - 382c. 8.Кришталь В.В. Сексологія / В.В. Кришталь, С.Р. Григорян. - М., Perse, 2012. - 878c. 9. Мигалкина И.С. Здоровье детей. Полная энциклопедия / И.С. Мигалкина. - СПб.: ИД "ВОТ", 2002. - 256 с. 10.Мэри Роуч. Секс для науки. Наука для секса / М. Роуч. - М., 2011. - С.320. 11.Обуховский К. Психология влечений человека /К. Обуховский. - М.: Просвещение, 1997. - 245 с. 12. Орлов Ю.М. Половое развитие и воспитание / Ю.М. Орлов. - М.: Просвещение, 1993. - 239 с. 13.Орлов Ю.М. Самопознание и самовоспитание характера / Ю.М. Орлов. - М $\therefore$ Просвещение, 1987. - 223 с. 14.Полз Рикёр. Сексуальность: чудо, заблуждение, загадка / П. Рикёр. - СПб: "Алетейя", 2002. - С.221 - 223. 15.Полная Энциклопедия "Жизнь и здоровье женщины". Том 1. - второй изд., испр. и доп. - М.: "Книжный дом" АНС ", 2002. - 768 с. 16.Фридман Л.М. Психология детей и подростков / Л.М. Фридман. М.: Изд. Института Психотерапии, 2003. - 480 с. 17.Холодный В.А. Медико-сексологическая модель психосексуального развития / В.А. Холодный//Вестник неврологии, психиатрии и нейрохирургии.- 2014, № 10.- С. 3 - 10.18.С o 1 i n Elland "Places of the Heart: The Psychogeography of everyday life." - М.: Аизпина Паблишер, 2016. - 282 p.

\section{ОСОБЕННОСТИ ПСИХОСЕКСУАЛЬНОГО РАЗВИТИЯ СОВРЕМЕННЫХ ШКОЛЬНИКОВ}

\section{С.М. Русина, Н.С. Карвацкая, В.И. Курык, Р.А. Никоряк, Т.Г. Карвацкая}

Резюме. Сексуальное здоровье - важная составляющая состояния здоровья человека и зависит не столько от биологических, сколько от психологических и социальных факторов, индивидуальной и общественной культуры, мотивации сексуального поведения.

Ключевые слова: психосексуальное развитие, сексуальное поведение и осведомленность, школьники.

\section{FEATURES OF PSYCHOSEXUAL DEVELOPMENT OF UP-TO-DATE SCHOOLCHILDREN}

\section{S.M. Rusina, N.S. Karvatska, V.I. Kuryk, R.A. Nikoriak, T.G. Karvatska}

Abstract. Sexual health is an important component of 
human health and depends not only on biological, but psychological and social factors, individual and general social culture, motivation of sexual behavior.

Keywords: psychosexual development, sexual behavior and awareness, schoolchildren.

Higher State Educational Establishment of Ukraine
"Bukovinian State Medical University", Chernivtsi Clin. and experim. pathol.- 2017.- Vol.16, №1 (59).-P.128-131.

Надійшла до редакиії 13.02.2017

Рецензент - проф. А.С. Борисюк

(C) С.М. Русіна, Н.С. Карвачька, В.І. Курик, Р.А. Нікоряк,

Т.Г. Карвацька, 2017 